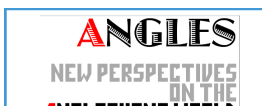
ANELOPHONE WORLD

\section{Angles}

New Perspectives on the Anglophone World

11 | 2020

Are You Game?

\title{
Consequence and Consequences in Jane Austen
}

Jean-Jacques Lecercle

\section{(2) OpenEdition}

\section{Journals}

Electronic version

URL: https://journals.openedition.org/angles/2373

DOI: $10.4000 /$ angles. 2373

ISSN: 2274-2042

\section{Publisher}

Société des Anglicistes de l'Enseignement Supérieur

\section{Electronic reference}

Jean-Jacques Lecercle, "Consequence and Consequences in Jane Austen", Angles [Online], 11 | 2020, Online since 01 November 2020, connection on 06 June 2022. URL: http://journals.openedition.org/ angles/2373 ; DOI: https://doi.org/10.4000/angles.2373

This text was automatically generated on 6 June 2022.

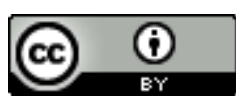

Angles est mise à disposition selon les termes de la Licence Creative Commons Attribution 4.0 International. 


\title{
Consequence and Consequences in Jane Austen
}

\author{
Jean-Jacques Lecercle
}

\section{Introduction}

1 How is it that, in my old age, I keep compulsively re-reading that glorified Mills and Boon romance they call Pride and Prejudice (hereafter PP) - a variation on the 'boy meets girl' romance in the bourgeois form of 'poor girl marries rich boy'? For what is Elizabeth Bennet if not the beggar maid that wins her King Cophetua? And yet I would take the novel with me to desert island.

2 It wasn't always so. When I first read the novel, at the age of 18 , I hated it. I was irritated by its reactionary conformism, its patriarchal ideology, its 'taming of the shrew' side, when Elizabeth Bennet renounces her ironic and independent posture and converts to Pemberley. And it is true that, in 1815, presenting Chatsworth or its fictional equivalent as the very symbol of the social cosmos, in the middle of the industrial revolution, of the Age of Enlightenment, after the French Revolution, Mary Wollstonecraft, Shelley and a host of others, is not a sign of historical or social awareness - hardly a Utopian anticipation of the future, rather a rear-guard action. How, therefore, can I take such pleasure in reading and re-reading the novel?

3 A naive answer is that, like all readers, I am captured into the fictional world of Jane Austen. With considerable narrative skill she lets me in, makes me feel at home in her world, to such an extent that I share the feelings and emotions of the characters, not least of her heroine, Elizabeth Bennet. It takes some talent to make a reader feel, two centuries later, that he shares the lives of the characters as if they were close relatives, or friends of the family.

4 I have just indulged in a number of danger words. For we know full well, in these structuralist and post-structuralist times, that characters of fiction, even if they seem to be as alive as our neighbours, are mere ghosts, whose ghostly existence is confined within a number of words and sentences, that they are constructed, sentence after 
sentence, as is linguistically furnished, page after page, the world in which they live. Therefore, if capture there is, the capture of fascination and seduction (of the reader by the text), such capture is strictly linguistic.

5 The best example of this is the very incipit of Pride and Prejudice, "It is a truth universally acknowledged, that a single man in possession of a good fortune, must be in want of a wife" (PP 1). At first reading, what we hear is the vox populi, a kind of maxim or proverb. At second reading, however, we become aware of a strange insistence, which is perhaps a symptom: the proverb states a truth, a truth universally acknowledged, presented as some sort of logical necessity, or at least probability (“...must be in want of a wife"). Methinks the proverb doth protest too much, and the whole thing smacks of Freudian negation. An impression confirmed when we read the third paragraph of the novel and realize the sentence was actually the wishful thinking of a foolish woman, Mrs Bennet, who has five daughters of marriageable age and an estate entailed in the male line - so that we are made to reinterpret the modal auxiliary, must, as an expression not of logical necessity or probability, but of obligation: the young man who has just taken Netherfield Park is under the obligation of marrying one of Mrs Bennet's daughters, which he dutifully does at the end of the novel. I have been captured into this fictional world by the author's skilful play on the possible meanings of a modal auxiliary.

6 This answer, however, is not sufficient. It doesn't tell us how we pass from such admirable use of the English language to the fictional universe in which we are captured. Here I need to make a short detour, by way of one of Adorno's letters to Walter Benjamin. It is dated September $6^{\text {th }}, 1936$ :

I experienced a similar shock when I read the first sentence of Schnitzler's Weg ins Freie: "Today Georg von Wergenthin sat at dinner alone". What gives us the right to write about someone as if we were capable of talking about him, as if we knew who he is? (Unless I am mistaken, the first sentence of Elective Affinities, with its tentative introduction of the characters' names, because of Goethe's infallible tact as regards the philosophy of history, already shows an awareness of the impossibility of this form of narrative). (Adorno 131, translation mine from the French)

7 It seems to me that Adorno, in the historical conjuncture we call modernity, is saying two things: that it is impossible to know someone; and that, therefore, it is impossible to tell that person's story as if we knew him or her. This has something to do with Adorno's cultural pessimism, a pessimism which at the time of writing could not yet be ascribed to the memory of Auschwitz, but found its cause in the coming to power of the Nazis.

8 Let us for a moment take what Adorno is telling us seriously: we have no right to claim knowledge of another person. We immediately note that this problem is at the heart of Pride and Prejudice, since prejudice consists in the conviction that, contrary to empirical evidence, one knows what the other person is, and since pride, the feeling of superiority induced by one's class position, has the same consequence. Adorno, following Benjamin, claims that such false knowledge is embodied in the process of naming the characters: naming someone amounts to claiming to know everything about him or her. This is the meaning of Adorno's allusion to the incipit of Elective Affinities (to which Benjamin devoted a whole essay). His "tentative introduction of the characters' names" alludes to the fact that the four main characters in Goethe's novel are only known by their first names or their profession (Edward, Charlotte, Ottilie, the 
captain), which does not preclude knowledge of their social condition (the novel begins with the sentence: "Edward, a rich baron in the prime of life..."), but fails to give us the impression that we know everything about the character. As Benjamin states in his essay, "all the names are merely Christian names, at least until the appearance of Mittler" (a symbolically important character, as his name means "intermediary", but whose actual presence in the narrative is rather intermittent) (Benjamin 289, translation mine from the French). So giving a character her full name implies a thorough knowledge of her (we are reminded of the opening of Emma: "Emma Woodhouse, handsome, clever, and rich..." - a narrative coup de force if there is any), whereas giving her only a first name implies a more prudent or tentative approach. The difference with Pride and Prejudice is obvious: the first character to be named, in the third paragraph of the novel, is "Mr Bennet", the second is "his lady", in other words Mrs Bennet, and neither is entitled to a Christian name. And do we know Darcy's Christian name? We do: he is called Fitzwilliam Darcy, but this rather cumbersome first name is used on only one occasion, when he signs the letter of explanation he gives Elizabeth Bennet, after she has rejected him. At this point one may object that the heroine does have a Christian name, as do all the Bennet sisters, Jane, Mary, Kitty and Lydia. But this is a question of social etiquette: in society, Jane, the eldest Bennet sister is "Miss Bennet". Elizabeth is "Miss Elizabeth Bennet" - she is entitled (or should I say sentenced) to a Christian name because she is only the second sister. We must therefore take it as a symptom that Darcy's first name is never used in the novel, even, on the last page, when he is safely married to Elizabeth.

9 It appears that, in Jane Austen, this form of naming, family names before first names, far from denoting an antiquated form of narrative, which our modernity has made impossible, is the very condition of her narrative, in so far as, for her, a narrative is a site for social games. This is made very clear in a passage in Mansfield Park (hereafter MP), a conversation between the virtuous Fanny Price and the flirtatious Mary Crawford. Both are in love with Edmund Bertram, Sir Thomas Bertram's second son, and therefore not the heir to the title. Mary Crawford the incipient socialite would fain marry him, if only his social prospects were better. Catching sight of Edmund Bertram who, in the company of Mrs Grant her sister, is coming to join them, she addresses Fanny thus:

'My sister and Mr Bertram - I am so glad your eldest cousin is gone that he may be Mr Bertram again. There is something in the sound of Mr Edmund Bertram so formal, so pitiful, so younger-brother-like, that I detest it.'

'How differently we feel!' cried Fanny. 'To me, the sound of Mr Bertram is so cold and nothing-meaning - so entirely without warmth or character! - it just stands for a gentleman, and that's all. But there is nobleness in the name of Edmund. It is a name of heroism and renown - of kings, princes and knights; and seems to breathe the spirit of chivalry and warm affections.'

'I grant you that the name is good in itself, and Lord Edmund Bertram or Sir Edmund Bertram sound delightfully; but sink it under the chill, the annihilation of a $\mathrm{Mr}-$ and Mr Edmund is no more than Mr John or Mr Thomas.' (MP 224)

Beneath this amorous contest, there lies an assessment of the importance of social status. And here, there is neither pride not prejudice: Fanny has no prejudice, only the deepest feelings (her preference for Christian names is a sure sign of this), and Mary Crawford has not reached the social heights that allow pride (but her insistence on titles shows that she is ready for it). But the essential features of the social game staged in Pride and Prejudice are already present. 
11 At least this is the point I would like to make. I take it as a way to connect the second answer to my initial question (as reader, I am captured by the language of Jane Austen) with the first (I am captured by the world her fiction creates). And I shall try to do this in the manner of Leo Spitzer, by looking at the occurrences of one word, consequence, as its various acceptations seem to me to frame the semantic programme on which the narrative of Pride and Prejudice is based. What drew my attention was that the term is often used, to the point of being typical of Jane Austen's style, especially in its now archaic acceptation, the most famous instance of which may be found in the opening of Mansfield Park:

About thirty years ago, Miss Maria Ward of Huntingdon, with only seven thousand pounds, had the good luck to captivate Sir Thomas Bertram, of Mansfield Park, in the county of Northampton, and to be thereby raised to the rank of a baronet's lady, with all the comforts and consequences of an handsome house and a large income. (MP 41)

"With all the comforts and consequences": the word refers to rank and station, it denotes a social status, and this meaning derives from a wider archaic acceptation, still heard in the phrase "to be of consequence to someone", where the word denotes importance, in this case emotional importance. My purpose is to contrast this use of the word with its more common use, where it means the effect of a cause.

\section{Consequence}

13 This, therefore, is my answer to my two initial questions (as well as to Adorno's objection). What attracts me in Pride and Prejudice is, of course, Jane Austen's extraordinary linguistic skill, in so far as it contributes to the creation of a world of fiction, and in so far as her language is the language of a moment in the history of the English language when the two main acceptations of consequence, importance and effect, coexisted. The main interest of such coexistence, which inscribes the narrative programme of Pride and Prejudice, is that it makes manifest that a natural language inscribes a world, in this case a social world, in other words that, to speak like Gramsci, "a language is a conception of the world." The language games that Jane Austen plays, which are the foundation of her storytelling games, of her narrative as game, imply a representation of the social world which the language inscribes, reflects and conditions.

14 This is why I must start with an attempt at historical semantics, by charting the metaphorical drift the word has undergone in history. In this, the NED will be of help. Here are the first three meanings of the word the dictionary gives:

1. A thing or circumstance which follows as an effect or result from something preceding.

2. The action or condition of following as a result upon something antecedent, the relation of result or effect to its cause or antecedent.

3. That which follows logically, a logical result or inference.

15 I omit meanings 4 and 5, which are derivations of meaning three, and I come to meanings 6 and 7:

6. Importance, moment, weight. Originating in the attributive phrase "of consequence", i.e. having issues or results, and therefore important.

7 a. In reference to persons. Importance in rank and position, social distinction. See 'quality'. 
7 b. Importance manifested by appearance or demeanour, dignity. has just met - it will take three volumes for Elizabeth to forgive him: "She is tolerable, but not handsome enough to tempt me; and I am in no humour at present to give consequence to young ladies who are slighted by other men." (PP 9) We are of course keenly aware of the dramatic irony of such pronouncement (the underlined $m e$, the 
time adjunct at present), and the consequence mentioned is a mixture of importance and social status - for Darcy, at this stage, there is no emotional consequence which is not first and foremost social, and this is the clearest mark of his pride.

We may also note that on two occasions the word consequence is in collocation with the two keywords of the novel, the words of the title. The first occurs when, Bingley having gone back to London, Elizabeth attempts to console a jilted Jane:

They [Bingley's family and friends] may wish many things besides his happiness, they may wish his increase of wealth and consequence; they may wish him to marry

a girl who has all the importance of money, great connections, and pride. (PP 122)

This may pass for a definition of consequence as status, in its connection with consequence as dignity: consequence means a mixture of fortune (in Mansfield Park, Edmund Bertram thus judges Mary Crawford: "She had only learnt to think nothing of consequence but money" [MP 425]), of social station ("great connections") and pride. Elizabeth probably has Darcy in mind as much as Bingley, and we note the contrast between happiness and consequence, which expresses Elizabeth's position before her conversion to Pemberley, that is to a positive form of social consequence, which, however, is never named as such. The parallel conversion of Darcy is described in the negative language of the renunciation to consequence: "Never had she seen him so desirous to please, so far from self-consequence, or unbending reserve as now, when no importance could result from the success of his endeavours" (PP 232).

Consequence as status and/or dignity naturally occurs in the same context as pride, whereas consequence as result of effect is to be found in the same contexts as prejudice. Thus, when Elizabeth, who has been made aware by Darcy's letter of the truth about Wickham, tells Jane how much she regrets her former praise of him, they have the following exchange:

'How unfortunate [says Jane] that you should have used such strong expressions in speaking of Wickham to Mr Darcy, for they do appear wholly undeserved.'

'Certainly. But the misfortune of speaking with bitterness is a most natural consequence of the prejudices I had been encouraging.' (PP 200)

It appears that consequence as status implies not so much dignity as pride, prejudices and unwelcome consequences. More than the cliché of 'poor girl marries rich boy', what the narrative of Pride and Prejudice is about is the consequences of consequence.

We still have to give an account of the various types of consequence as importance or status that we find in both novels. They are three: social consequence, emotional consequence and moral consequence. Placing them in that order suggests a possible move from one to the other, produced by the consequences that each type of consequence implies.

Social consequence has characteristics one easily imagines: it comes with material comfort, money, the part one plays in society. In Mansfield Park, if the flirtatious Mary Crawford hesitates to accept Edmund Bertram, it is because he is not the heir to the title, and, even worse, he means to take orders. She even dares to tell him so to his face: "You assign greater consequence to the clergyman than one has been used to hear given, or than I can quite comprehend." (MP 120) It will come as no surprise that this type of consequence has psychological consequences - snobbery, giving in to flattery, pride, and even quasi-physiological consequences: you can tell a person of consequence from the way he or she dresses, walks or speaks. Sir Thomas Bertram walks in a slow and majestic manner. His wife, Lady Bertram, is completely motionless. Mr Darcy, when 
he enters the ballroom at the beginning of the novel, is a fine figure of a man because he has a yearly income of ten thousand pounds:

The ladies declared he was much handsomer than Mr Bingley, and he was looked at with great admiration for about half an evening, till his manners gave a disgust which turned the tide of his popularity; for he was discovered to be proud, to be above his company, and above being pleased; and not all his huge estate in Derbyshire could then save him from having a most forbidding, disagreeable countenance, and being unworthy to be compared with his friend. (PP 7-8)

31 As we can see, social consequence has consequences, not all of which are felicitous: whether or not it implies pride, it can make you handsome, or plain. Indeed, if in Pride and Prejudice social consequence is tainted by pride in the character who embodies it, in Mansfield Park, its consequences are of a more serious and long lasting kind: in Maria Bertram, it encourages selfishness (which in both novels is called "self-consequence"), fosters false values and illusions. More than anything else, it provokes the catastrophe: when she, the eldest daughter of Sir Thomas Bertram, has just married the insignificant but rich Mr Rushworth, she elopes with Henry Crawford, and ends up in disgrace and exile. In Mansfield Park, the catastrophe takes us through the whole gamut of the consequences of consequence. In Pride and Prejudice, Maria's fate is spared Lydia (who has eloped with Wickham), but only through Darcy's last-minute intervention. And this is no simple deus ex machina: Darcy's intervention is due to his recently acquired awareness of another type of consequence, emotional consequence. In the famous scene when he first proposes to Elizabeth, such awareness still eludes him, thus justifying Elizabeth's indignant rejection:

His sense of her inferiority - of its being a degradation - of the family obstacles which judgement had always opposed to inclination, were dwelt on with a warmth which seemed due to the consequence he was wounding, but was unlikely to recommend his suit. (PP 168)

The consequence referred to here is of course Darcy's social consequence, which he finds it difficult to ignore. But am I forcing the text in reading the phrase "the consequence he was wounding" as ambiguous? For in speaking thus, he inflicts another kind of wound, on the emotional consequence of which Elizabeth, together with Jane, is the embodiment in the novel.

In Mansfield Park, the status of emotional consequence is ambiguous, and does not entail the same consequences. In Maria Bertram, it takes the form of forbidden passion and leads to adultery and ruin. Henry Crawford, before he persuades Maria to elope with him, is in love with Fanny Price, who does not find his attentions welcome, as she has doubts, which will later be confirmed, about his morality:

He was in love, very much in love; and it was a love which, operating on an active, sanguine spirit, of more warmth than delicacy, made his affection appear of greater consequence, because it was withheld, and determined him to have the glory, as well as the felicity, of forcing her to love him. (MP 325)

That consequence is nefarious. It easily combines with social consequence, as it affects the same characters. But in Fanny Price and Edmund Bertram, emotional consequence takes on another, thoroughly positive, value: it is no longer a case of passion, of devastating inclination, but of affection and selfless love. To be important to someone else (which is, as we saw, what Fanny wished to be in relation to her aunt), and especially to feel the importance to oneself of another being, to give affection as well as being the recipient of it, this is the consequence the acquisition of which Fanny Price's 
success story relates. Said acquisition is well on the way in chapter 22: "Fanny's consequence increased on the departure of her cousins." (MP 219)

Mansfield Park, this consequence is explicitly mentioned only once, but at a turning point of the plot. Sir Thomas Bertram has departed for the West Indies, to look after his estates. As a result, the young people feel free of all moral restraint: they wish, horribile dictu, to stage a play. They all give in to that wind of folly, even the wise Edmund Bertram, and the rehearsals are as many opportunities for flirtatious behaviour (this is when Maria Bertram's passion is given free rein, although she is already engaged to $\mathrm{Mr}$ Rushworth). The only one who resists is Fanny, who in so doing makes the abyssal depth of her virtue (a virtue hardly bearable for today's reader) manifest:

Fanny looked in and listened, not unamused to observe the selfishness which, more or less disguised, seemed to govern them all, and wondering how it would end. For her own gratification she could have wished that something might be acted, for she had never seen even half a play, but every thing of higher consequence was against it. (MP 156)

As we can see, moral consequence is called "higher consequence". And it appears that the theatre is a site for an evil form of consequence, the selfishness and vanity of selfconsequence, and its evil nature will be made clear later in the novel, in Maria Rushworth's ruin - in divorce and exile.

path of consequence, which at the heart of the plot in Mansfield Park, may be represented in the following manner. Social consequence, which is an objective reality (as exemplified by Sir Thomas Bertram, baronet) entails two opposite types of emotional consequence: either "self-consequence", i.e. selfishness, irresponsibility, social pride, or sound affection and selfless humility, everything that goes under the name of dignity in the most positive sense of the word. Both consequences themselves have consequences, as selfishness leads to social chaos and personal ruin ("What would be the consequences? Whom would it not injure? Whose views might it not affect? Whose peace would it not cut up for ever" [MP 480], thus Fanny Price when she learns of Maria Bertram's elopement), whereas selflessness leads to moral "higher consequence" and to a newly found cosmos, both social and personal. On the one hand, Maria Bertram, whose fate is presented as an example not to be followed, on the other hand Fanny Price, whose success is exemplary in the opposite sense, and whose personal trajectory follows the path of consequence - at the beginning of the novel, she is still outside the pale, for lack of social consequence (a pauper niece that charity has allowed to enter the great house), but at the end she has found her place at the very centre, as the return to cosmos after chaos is largely due to her apparently insignificant person.

What is implicit in this trajectory is that social consequence, the negative aspects of which have been focused on so far, has a positive side, the source of dignity rather than pride. This positive aspect is spectacularly present in Pride and Prejudice. If Elizabeth Bennet undergoes her conversion, it is not of course simply out of social ambition, it is out of her recognition that Pemberley is not merely a myth, but the embodiment of a social, but also an ethical responsibility, and therefore of a form of dignity.

Thus, the path of consequence in Pride and Prejudice may be represented in the following manner. It links, or seeks to link, two poles, social versus emotional consequence. Either pole has its positive, as well as its negative aspect, according to the 
psychological consequences it entails: pride or dignity for social consequence, humility or selfishness ("self-consequence") for emotional consequence. The characters each embody a trajectory along that path, like pawns in a game of chess. The negative aspect of each pole entails material consequences, the effect of the psychological consequences just mentioned, and the trajectory ends on failure: Lady Catherine de Burgh remains a prisoner of her pride and selfishness, Lydia and Wickham will never obtain the social consequence they crave for. The positive aspect entails the opposite consequences: Jane, whose feelings are as humble as they are deep, eventually marries her Bingley; before the beginning of the plot, Darcy's father, aware of the moral responsibility that his station ought to carry, had been the benefactor of an ungrateful Wickham. Darcy and Elizabeth begin their respective journeys from the negative side of their respective poles - from pride and from prejudice, and they end up at the positive side of the opposite pole, respectively acquired humility for the great man and conversion to tradition for the ironic and rebellious young lady. At their middle point, their trajectories cross, and at the end of the novel everything is as it should be.

I have just used a metaphor, of consequence as a game. But is it merely a metaphor? My contention is that it is not.

\section{A game of consequences} the eighth meaning of consequence in the NED:

8. Consequences. A round game, in which a narrative of the meeting of a lady and a gentleman, their conversation and the ensuing 'consequences' is concocted by the contribution of a name or a fact by each of the players, in ignorance of what had been contributed by the others.

example that illustrates this meaning is taken from Sense and Sensibility: "They met for [...] playing at cards or consequences, or any game that was sufficiently noisy" (S\&S 133).

"Sufficiently noisy": the game was obviously a great source of fun. It still exists today, albeit in a simpler form, as it has an equivalent in the Surrealist game of cadavre exquis: the first player begins a story, and passes it on to the next, hiding all but the last sentence, on the basis of which the new player will continue the narrative, and so on and so forth. The story thus "concocted" will eventually be read aloud, among general hilarity. This modern version, however, differs from the game as played at the time of Jane Austen in one important respect: in the older version, it wasn't any story that was concocted, it was the eternal and ever exciting story of a lady and a gentleman, and of the consequences, sometimes surprising but always in a sense predictable, of their meeting.

We know that social games and rituals play a large part in Jane Austen's world. More often than not they are rituals that allow young people of both sexes to meet and converse without a chaperone. Whist is for older, in other words married, people. But we are aware of the central importance, in the narrative as well as the ethical structure of Mansfield Park, of the theatre, with its amorous duets, and the innumerable rehearsals the staging of the play demands. And the same can be said of the ballroom scene in Pride and Prejudice, even if it occurs at the beginning of the story rather than at its significant middle point. For it is then, in Darcy's assessment of Elizabeth, that pride 
is made manifest and prejudices are born. Even if Darcy and Elizabeth do not dance together, because they do not dance together, they enter an amorous game which provides the novel with its narrative thread.

I therefore suggest we read Pride and Prejudice as the development, in the shape of a novel, of a game of consequences, as it is in that kind of game that the dialectics of the too well known (the clichés of the romance plot, the ever retold tale of Cinderella) and the surprising is played out. The problem of the couple in the making, what prevents them, for our pleasure, to come together before the end of the third volume, is indeed "the ignorance of what is contributed by the other". For Elizabeth and Darcy, the consequence of their clinging to a bad consequence (social in the case of Darcy, emotional for Elizabeth) is not ruin (a fate that threatens Lydia) or failure (Lady Catherine de Burgh, unlike the ridiculous Mrs Bennet, will not succeed in marrying her daughter), it is their ignorance of the true feelings of the other, with its consequent misunderstandings.

We understand why the characters, even the protagonists, even the more rounded (as opposed to flat) characters, are what narratologists call actants - pieces in a game of chess, whose moves, like Alice's moves on the chessboard of Through the Looking-Glass, are determined by the strategic and tactical demands of the game. The legendary 'lightness' of Pride and Prejudice (and it is a short step from 'light' to 'slight'), its Mills and Boon side, from which I started, as the novel doesn't lay claim to the moral depth of Mansfield Park, may be positively reinterpreted in terms of the game: if the brilliant Elizabeth Bennet, contrary to the boring Fanny Price, crushed by her own virtue, is endowed with eternal charm, it is not because she is vivacious and sardonic, it is because she is a pawn in the game of chess, or rather of consequences, of the novel, a pawn who, in the literal as in the figurative sense, goes to queen. Or rather, her charming psychological traits are merely the attributes of the role she plays in a game of consequences.

We have moved from a linguistic to a semiotic account, from the meanings of the word consequence that give the novel its semantic programme to the structure of the novel as game, with its rules, its moves, its strategy and tactics. This is where we may combine the two answers to my initial question (which was based on a purely emotional reaction). If, like Greek art for Marx (in a famous passage of the Grundrisse), Pride and Prejudice is endowed with "eternal charm", it is because the fictional world of the novel has lost nothing of its captivating power, which is the captivating power of a game: every reader starts the game afresh, each new reader is a potential player.

We also understand why Jane Austen, unwittingly and in anticipation, has answered Adorno's objection about the impossibility of this type of narrative. For her, the object of a narrative is the representation of a social game, a game of ritual and etiquette, carried along by linguistic agon (her typical conversations are so many linguistic contests), and this is where the novel reaches the reality of a society in a determinate historical conjuncture, which the reader is able to recontextualize. In Goethe's novel, the characters are molecules caught in the chemical game of elective affinities - all they need is a Christian name. In Jane Austen, emotions and feelings are filtered through a language in so far as it expresses a conception of the world, in other words, a culture. Two centuries later, society has changed, but the linguistic and pragmatic game of amorous relationship is still with us. What fascinates me in Pride and Prejudice (to the point of taking the novel with me to desert island) is both the historical distance 
(inscribed in the archaic meaning of consequence) and the ever renewed and successful recontextualization, in other words, the dialectics of consequence and consequences.

\section{BIBLIOGRAPHY}

Adorno, Theodor W. Sur Walter Benjamin. Paris: Allia, 1999.

A New English Dictionary on Historical Principles: Founded Mainly on the Materials Collected by the Philological Society. Ed. James A. H. Murray. Oxford: Clarendon Press, vol. 2 (C), 1893. Referenced as NED.

Austen, Jane. Pride and Prejudice [1813]. Ed. James Kinsley. Oxford: Oxford UP, 1980. Referenced as PP.

Austen, Jane. Mansfield Park [1814]. Ed. Kathryn Sutherland. Harmondsworth: Penguin, 1966. Referenced as MP.

Austen, Jane. Sense and Sensibility [1811]. Ed. Devoney Looser. New York: Penguin, 2018. Referenced as S\&S.

Benjamin, Walter. "Les Affinités électives de Goethe." In Euvres. Vol. 1. Trans. and Ed. Maurice de Gandillac, Rainer Rochlitz and Pierre Rusch. Paris: Gallimard, 2000. 274-283.

\section{ABSTRACTS}

This reading of Pride and Prejudice and Mansfield Park suggests that the semantic framework of the novels is provided by the contrast between two meanings of the word consequence, the archaic meaning of social or emotional importance and the common and garden meaning of effect of a cause. It also suggests that the narrative structure of the novels is that of a game of consequences, a game that was played at the time of Jane Austen.

Nous proposons la thèse suivante : le cadre sémantique des romans Orgueil et préjugé et Mansfield Park est créé par le contraste entre les deux sens du mot "consequence", incluant le sens archaïque d'importance sociale ou émotionnelle, et le sens commun et habituel qui dit l'effet produit par une cause. Nous suggérons également que la structure narrative des romans est un jeu de conséquences (« a game of consequences »), un jeu pratiqué à l'époque de Jane Austen.

\section{INDEX}

Keywords: Adorno Theodor, Austen Jane, consequence, consequences, dignity, Goethe Johann Wolfgang von, narrative structure, prejudice, pride, semantic programme, game

Mots-clés: Adorno Theodor, Austen Jane, conséquence, conséquences, dignité, Goethe Johann Wolfgang von, structure narrative, préjugé, orgueil, programme sémantique, jeu 


\section{AUTHOR}

\section{JEAN-JACQUES LECERCLE}

Professor Emeritus at the University of Paris Nanterre. He is the author of many books, including Philosophy Through the Looking-Glass (1985), The Violence of Language (1991), Philosophy of Nonsense (1994), Interpretation as Pragmatics (1999), Deleuze and Language (2002), The Force of Language (2004), A Marxist Philosophy of Language (2006), Badiou and Deleuze Read Literature (2010), De l'InterpellationSujet, Langue, Idéologie (2019). 